\title{
Article \\ Effects of Repeated Application of Organic Soil Amendments on Horticultural Soil Physicochemical Properties, Nitrogen Budget and Yield
}

\author{
Sarah Duddigan ${ }^{1, *(\mathbb{D})}$, Paul D. Alexander ${ }^{2,3}{ }^{\text {, Liz J. Shaw }}{ }^{1}$ (D) and Chris D. Collins ${ }^{1}$ \\ 1 Department of Geography and Environmental Science, University of Reading, Reading RG6 6DW, UK; \\ e.j.shaw@reading.ac.uk (L.J.S.); c.d.collins@reading.ac.uk (C.D.C.) \\ 2 Department of Horticultural and Environmental Science, Royal Horticultural Society, Wisely GU23 6QB, UK; \\ pda@bulrush.co.uk \\ 3 Department of Technical Support and Product Development, Bulrush Horticulture Ltd., Co., \\ Londonderry BT45 8ND, UK \\ * Correspondence: s.duddigan@reading.ac.uk
}

check for updates

Citation: Duddigan, S.; Alexander, P.D.; Shaw, L.J.; Collins, C.D. Effects of Repeated Application of Organic Soil Amendments on Horticultural Soil Physicochemical Properties, Nitrogen Budget and Yield. Horticulturae 2021, 7, 371. https:// doi.org/10.3390/horticulturae7100371

Academic Editor: Douglas

D. Archbold

Received: 2 September 2021

Accepted: 4 October 2021

Published: 7 October 2021

Publisher's Note: MDPI stays neutral with regard to jurisdictional claims in published maps and institutional affiliations.

Copyright: (c) 2021 by the authors. Licensee MDPI, Basel, Switzerland. This article is an open access article distributed under the terms and conditions of the Creative Commons Attribution (CC BY) license (https:/ / creativecommons.org/licenses/by/ $4.0 /)$.

\begin{abstract}
Application of organic amendments to soil is commonplace in domestic gardening. However, a vast array of materials could be labelled as 'compost' by retailers and suppliers. We investigated six different amendments currently used, or available for use, in horticulture: composted bark, composted bracken, spent mushroom compost, composted horse manure, garden waste compost (at two different application rates), and peat. Using a controlled field experiment, we examined the physicochemical differences between the amendments, the subsequent effects on soil characteristics, and resultant yield and biometrics of Lavatera trimiestris. Amended soils resulted in a significantly different multivariate soil environment and $\mathrm{N}$ budget when compared to the unamended control. However, the effect on yield and plant biometrics (number of flowers, plant height, etc.) depended on the amendment used. Application of garden compost resulted in up to a five-fold increase in yield. However, there was no significant difference in yields in soils amended with composted bark or peat, when compared to the unamended control. This has implications, as there is increasing pressure to remove peat from products available to domestic gardeners. The variability in the different amendments investigated in our research, in addition to the variable effects on plant growth parameters, suggests that repeated use of a single amendment may not be best practise for gardeners.
\end{abstract}

Keywords: organic amendments; compost; peat; horticulture; gardening; garden soil; nitrogen budget; Lavatera trimestris

\section{Introduction}

Both commercial and domestic horticulturalists recognise that soil organic matter (SOM) is critical for plant production [1]. The presence of SOM can stimulate the growth of plants sown in the medium both directly, through stimulating seed germination and root initiation [2,3], and indirectly through improving soil characteristics favourable for subsequent plant growth. Such as provision of nutrients, improved soil structure and water holding capacity [3-5]. However, intensive horticultural cropping methods, combined with poor management, can lead to depletion in SOM stocks and a decline in soil fertility and health [6]. In agriculture and commercial horticulture, a number of practices can enhance SOM contents including reduced tillage, residue management, crop rotations, cover crops and organic amendments [7]. Domestic horticulturalists or gardeners, however, often favour application of organic amendments to their soils, in part due to crop rotations and cover crops not being practical in perennial flower beds [8].

Organic amendments can improve structure, nutrient distribution [3,5], bulk density, $\mathrm{pH}$ and salinity of soil [9]. Biological breakdown of SOM liberates nutrients once held 
in organic polymers, making them available for utilisation by plants for growth [10]. Advisory literature for gardeners emphasises the importance of $\mathrm{N}$ as the most significant macronutrient, and applying organic amendments can be a significant source of organic $\mathrm{N}$ to garden soils (providing an alternative to inorganic fertilisers) $[8,11,12]$.

However, the increase in nutrient supply to plants as a result of organic amendments can be significantly different depending on the quality of the amendment used and its application rate [4]. Selection of organic amendments that are suitable for use in horticultural systems are often driven by the following factors: (i) they are available in large amounts; (ii) they are as homogeneous as possible; (iii) they are low in price; and (iv) they have minimal transport costs [13]. Alexander and Nevison [1] suggested the decision-making priorities for gardeners primarily considered; availability, cost, effectiveness and aesthetics. Furthermore, gardeners are "creatures of habit"; once they have identified a material they like, they tend to utilise it repeatedly.

Gardeners recognise the potential for cost savings and environmental benefits associated with the use of organic amendments, e.g., reduced use of fertilisers, and may not be so driven by the cost or availability of a material, but its effectiveness. Therefore, an understanding of the differences associated with amendment selection is vital for gardeners. Particularly as any of these materials could be labelled as 'compost' by retailers and suppliers.

With respect to the effectiveness of an amendment, assessing the influence of amendment composition on promoting yield is extremely complex and requires an understanding of a wide range of chemical, physical and biological variables associated with the amendment [14] and the effects of amendment application on the multivariate soil environment.

This research used a controlled field experiment in Wisley (UK) which had received six years of repeated application of organic amendments. Previous work on the site has reported that repeated application of organic amendments has impacted on individual soil properties (e.g., $\mathrm{pH}$, bulk density) over time [1]. Here, we aim to examine soil physicochemical properties on a multivariate basis, along with $\mathrm{N}$ budget, and resultant yield and plant biometrics. All experiments were conducted within a horticultural context in order to aid both domestic and commercial horticulturalists to make more informed decisions when selecting organic amendments.

The hypotheses we intend to address in this research are as follows:

1. Organic amendments commonly used in horticulture are variable in terms of their physicochemical properties ( $\mathrm{pH}$, bulk density, nutrient content, etc.)

2. Application of organic amendments will alter the multivariate soil physicochemical environment and $\mathrm{N}$ budget, and the extent of change compared to the control will depend on the amendment applied

3. There will be a subsequent effect of amendment application on plant production

\section{Materials and Methods}

\subsection{Experimental Site}

The study site, described by Alexander and Nevison [1], was established at the Royal Horticultural Society's (RHS) Deers Farm site in Wisley, UK $\left(51.323428^{\circ} \mathrm{N},-0.474392^{\circ} \mathrm{W}\right)$ on a sandy loam soil (Table 1). The site consisted of $3 \mathrm{~m} \times 3 \mathrm{~m}$ plots in a randomised complete block alignment ( 8 blocks, 8 replicates) treated annually with the following amendments: Irish moss peat (Peat); composted horse manure (HM), garden compost at full rate (GCf) and half rate (GCh) from collected prunings and cuttings from RHS Wisley Garden; composted bracken (Br) Pteridium aquilinum L. Kuhn blended with animal manure; composted bark (Bk); and spent mushroom compost (M), a by-product of the mushroom industry, which is a blend of wheat straw, gypsum and animal manure. In addition to a control treatment where no amendments were applied. 
Table 1. Initial soil conditions $(0-15 \mathrm{~cm})$ of field site in year 0 (before any amendments were applied).

\begin{tabular}{|c|c|c|}
\hline & Mean \pm Standard Error $(n=80)$ & Method * \\
\hline $\mathrm{pH}$ & $5.90 \pm 0.06$ & 1:2 soil/deionised water \\
\hline OM Content (\%) & $6.06 \pm 0.16$ & Loss on ignition (LOI) \\
\hline Bulk Density $\left(\mathrm{g} \mathrm{cm}^{-3}\right)$ & $1.01 \pm 0.01$ & Cylinder and driving tool \\
\hline Particle Size Distribution & & $\mathrm{H}_{2} \mathrm{O}_{2}$, sedimentation and sieving \\
\hline Sand $(\%)$ & $79.91 \pm 0.17$ & \\
\hline Silt $(\%)$ & $9.29 \pm 0.17$ & \\
\hline Clay $(\%)$ & $10.80 \pm 0.19$ & \\
\hline \multicolumn{3}{|c|}{ Extractable Nutrients $\left(\mathrm{mg} \mathrm{kg}^{-1}\right)$ : } \\
\hline $\mathrm{P}$ & $999.81 \pm 46.60$ & $\mathrm{NaHCO}_{3}($ Olsen $\mathrm{P})$ extraction \\
\hline K & $933.00 \pm 28.00$ & $\mathrm{NH}_{4} \mathrm{NO}_{3}$ extraction \\
\hline $\mathrm{B}$ & $7.31 \pm 0.32$ & Hot water extraction \\
\hline $\mathrm{Cu}$ & $38.74 \pm 2.46$ & EDTA $^{* *}$ extraction \\
\hline $\mathrm{Fe}$ & $1232.06 \pm 48.7$ & DPTA $^{* * *}$ extraction \\
\hline $\mathrm{Mg}$ & $422.13 \pm 8.79$ & EDTA extraction \\
\hline $\mathrm{Mn}$ & $34.28 \pm 1.85$ & DPTA extraction \\
\hline $\mathrm{SO}_{4}$ & $174.82 \pm 4.40$ & Phosphate buffer extraction \\
\hline $\mathrm{Zn}$ & $142.24 \pm 21.80$ & EDTA extraction \\
\hline
\end{tabular}

* All analyses carried out according to [15] by NRM Laboratories (Bracknell, UK). ${ }^{* *}$ Ethylenediaminetetraacetic acid (EDTA). ${ }^{* * *}$ Diethylenetriaminepentaacetic acid (DPTA).

The choice of materials was based on those commonly used in UK horticulture (M, GC, Peat and HM), those widely available to UK horticulture (Bk) and material that could be available to UK horticulture (Br). With the exception of the garden compost, all amendments were purchased as commercial products annually, from the same suppliers. The garden compost was generated on site using plant waste arising from and RHS botanical garden in Wisley; plant wastes were stockpiled, shredded and then windrow composted for 6-9 months before use (windrows turned monthly).

A $1 \mathrm{~m}$ path between each plot was maintained and all soil and plant sampling was conducted in the central $2 \mathrm{~m} \times 2 \mathrm{~m}$ portion of the plot, to minimise boundary effects.

Organic amendments were applied annually in early spring as a $5 \mathrm{~cm}$ layer on the surface of the soil. This application rate was selected to mimic common practice by gardeners and to be in line with current Royal Horticultural Society advise [12]. In order to examine the effects of application rate, a half-rate garden compost treatment which was applied at $2.5 \mathrm{~cm}$ was included. The control treatment had no amendments applied, but plants were still sown. Amendments were promptly incorporated into the top $15 \mathrm{~cm}$ of soil with the use of a tractor-mounted rotovator. In Year 0 , no organic material was applied to any plots, in order to identify any natural baseline variations.

Different horticultural plants were also grown annually from seed, in order to better represent the garden scenario (see Supplementary Information, Table S1). However, plant data presented in this paper were collected in year 7 when Lavetera trimestris was grown (Table S1). All plants were hand sown by station $(15 \mathrm{~cm}$ spacing) in spring and harvested in the autumn. Although no amendments were applied in Year 0, plants were grown to verify the absence of any natural baseline variation between the plots before experimentation commenced (data not shown-see [1]).

\subsection{Soil and Amendment Sampling and Analysis}

Three replicate subsamples were taken from each amendment, each year, to be analysed. In the case where amendments were delivered in a bulk load, subsamples were taken from three different places within the pile. In the case where amendments were delivered in bags, subsamples were taken from three different bags. Results presented are the mean of the 3 subsamples taken each year, with the exception of year 7 where the individual results for each subsample are available.

Soil samples were taken twice in Year 7: once before the season's organic amendments were applied (March), and once after the season's crops had been harvested (September). 
Plots were auger sampled at $0-15 \mathrm{~cm}$ depth from 3 positions within the central $2 \mathrm{~m} \times 2 \mathrm{~m}$, and homogenised, before taking a subsample for analysis.

Laboratory analyses were conducted externally by NRM laboratories (Bracknell, UK) for: $\mathrm{pH}$; extractable $\mathrm{N}, \mathrm{P}, \mathrm{K}, \mathrm{B}, \mathrm{Ca}, \mathrm{Cu}, \mathrm{Fe}, \mathrm{Mg}, \mathrm{Mn}, \mathrm{Na}, \mathrm{SO}_{4}, \mathrm{Zn}$; loss on ignition; and cation exchange capacity (soils only). All analyses were conducted according to the The Ministry of Agriculture, Fisheries and Food (MAFF, London, UK) Bulletin RB 427 [15]. Dry-bulk density of the soil in the plots was also measured in March and September of Year 7 using a standard cylinder and driving tool method. Samples were weighed and dried at $105^{\circ} \mathrm{C}$, so that gravimetric soil moisture content could also be determined. The density of the amendments applied was determined by NRM laboratories using $\mathrm{H}_{2} \mathrm{O}_{2}$, sedimentation and sieving. Soil subsamples were also ground using a TEMA mill and analysed for total $\mathrm{C}$ and N content on a Thermo Scientific Flash 2000 CN Analyser.

\subsection{Plant Sampling and Analysis}

Dry-bulk yield of Lavatera trimestris on each plot was measured at harvest, in September Year 7. Plots were harvested at ground level (no roots). Above ground, plant biomass was weighed and a subsample was dried at $80^{\circ} \mathrm{C}$ for $48 \mathrm{~h}$ to determine moisture content, making gross wet and dry biomass available for each plot. Subsamples of above-ground plant material from each plot were also removed for nutrient tissue analysis. Plant tissue analyses were conducted by NRM laboratories according to the MAFF Bulletin RB 427 [15] for total N, P, K, B, Ca, Cu, Fe, Mg, Mn, S and Zn. Plant samples were a mixture of stem and leaves, with flowers removed.

Eight weeks after sowing, the number of plants growing on the plots were counted, as well as the number of plants with flowers. Four plants were also selected at random within the central $2 \mathrm{~m} \times 2 \mathrm{~m}$ to avoid potential boundary effects. The height of these plants was measured as well as the chlorophyll content of 3 fully developed leaves on each plant using a Soil Plant Analysis Development (SPAD) chlorophyll meter (Konica Minolta, Tokyo, Japan). Mean plant height and chlorophyll content was calculated for each plot.

\subsection{Nitrogen Budget}

A partial $\mathrm{N}$ budget was calculated for each plot based on $\mathrm{N}$ additions in Year 7 (amendment) and $\mathrm{N}$ removals (harvest of plant biomass $\mathrm{N}$ ) per plot, as follows:

$$
N \text { budget }\left(\mathrm{kg} \mathrm{m}^{-2}\right)=N \text { additions }\left(\mathrm{kg} \mathrm{m}^{-2}\right)-N \text { removals }\left(\mathrm{kg} \mathrm{m}^{-2}\right)
$$

Plant N-use efficiency (NUE) was also calculated as follows:

$$
\text { NUE }=\left(\frac{N \text { additions }\left(\mathrm{kg} \mathrm{m}^{-2}\right)}{N \text { removals }\left(\mathrm{kg} \mathrm{m}^{-2}\right)}\right) \times 100
$$

\subsection{Statistical Analysis}

Multivariate analysis of physicochemical properties used multidimensional scaling (MDS) and analysis of similarity (ANOSIM) using a Euclidean distance resemblance matrix was conducted in Primer (Version 6).

All other statistical analyses were conducted using Minitab (20.0). Statistical analysis of single variables comprised of analysis of variance (ANOVA), with Tukey's post hoc testing $(p<0.05)$. Before ANOVA was conducted, treatments were tested for equal variance using a Levenes test, and data were transformed if necessary to satisfy a Levenes test.

\section{Results}

\subsection{Amendment Properties over 7 Years of Sampling}

Multidimensional scaling of the amendment physicochemical data (e.g., $\mathrm{pH}$ bulk, $\mathrm{C}$ content, etc.), and subsequent analysis of similarity (ANOSIM) show that each amendment is significantly different from one another (Table 2). 
Table 2. Pairwise comparisons of amendments' multivariate physicochemical properties before application. $p$ values according to ANOSIM. Data from 7 years of sampling amendments.

\begin{tabular}{cccccc}
\hline & $\begin{array}{c}\text { Spent } \\
\text { Mushroom } \\
\text { Compost }\end{array}$ & $\begin{array}{c}\text { Garden } \\
\text { Compost }\end{array}$ & $\begin{array}{c}\text { Composted } \\
\text { Bark }\end{array}$ & $\begin{array}{c}\text { Composted } \\
\text { Bracken }\end{array}$ & $\begin{array}{c}\text { Composted } \\
\text { Horse } \\
\text { Manure }\end{array}$ \\
\hline $\begin{array}{c}\text { Garden } \\
\text { Compost } \\
\text { Composted } \\
\text { Bark }\end{array}$ & 0.002 & 0.002 & 0.001 & & \\
$\begin{array}{c}\text { Composted } \\
\text { Bracken }\end{array}$ & 0.001 & 0.001 & 0.002 & \\
$\begin{array}{c}\text { Composted } \\
\text { Horse }\end{array}$ & 0.001 & 0.001 & 0.001 & 0.002 & \\
Manure & 0.001 & 0.001 & 0.001 & 0.003 & 0.001 \\
\hline Peat & & & & \\
\hline
\end{tabular}

Peat, for example, was characterised by low $\mathrm{pH}$, low density, and low extractable N, P and $\mathrm{K}$ (Table 3), compared with garden compost which had a high $\mathrm{pH}$ and density, and spent mushroom compost with a high total extractable $\mathrm{N}, \mathrm{P}$ and $\mathrm{K}$ content. The majority of the extractable $\mathrm{N}$ in spent mushroom compost was ammonia- $\mathrm{N}$, and was significantly higher than the other amendments (Table 3). Garden compost and peat had significantly higher concentrations of nitrate- $\mathrm{N}$ than the other amendments (Table 3).

Table 3. Physicochemical characteristics of amendments applied. Mean of amendments \pm standard error over 7 years. Treatments that share the same letter suffix, in the same column, had no significant difference according to one-way ANOVA and Tukey's post hoc testing $(p>0.05)$.

\begin{tabular}{cccccccc}
\hline Treatment & $\mathbf{p H}$ & $\begin{array}{c}\text { Bulk Density } \\
\left(\mathbf{g ~ c m} \mathbf{~ c m}^{-3}\right)\end{array}$ & $\begin{array}{c}\text { Total } \\
\text { Extractable N } \\
(\mathbf{m g} / \mathbf{k g})\end{array}$ & $\begin{array}{c}\text { Extractable } \\
\text { Ammonia-N } \\
(\mathbf{m g} / \mathbf{k g})\end{array}$ & $\begin{array}{c}\text { Extractable } \\
\text { Nitrate-N } \\
(\mathbf{m g} / \mathbf{k g})\end{array}$ & $\begin{array}{c}\text { Extractable P } \\
(\mathbf{m g} / \mathbf{k g})\end{array}$ & $\begin{array}{c}\text { Extractable K } \\
(\mathbf{m g} / \mathbf{k g}\end{array}$ \\
\hline $\begin{array}{c}\text { Composted } \\
\text { Bark }\end{array}$ & $6.08 \pm 0.10_{\mathrm{c}}$ & $0.176 \pm 0.005_{\mathrm{bc}}$ & $678 \pm 207_{\mathrm{b}}$ & $639 \pm 205_{\mathrm{b}}$ & $39 \pm 5_{\mathrm{b}}$ & $4646 \pm 298_{\mathrm{ab}}$ & $3956 \pm 215_{\mathrm{b}}$ \\
$\begin{array}{c}\text { Composted } \\
\text { Bracken }\end{array}$ & $6.99 \pm 0.43_{\mathrm{bc}}$ & $0.103 \pm 0.008_{\mathrm{d}}$ & $871 \pm 245_{\mathrm{b}}$ & $622 \pm 215_{\mathrm{b}}$ & $249 \pm 115_{\mathrm{b}}$ & $6584 \pm 3154_{\mathrm{ab}}$ & $19583 \pm 6220_{\mathrm{b}}$ \\
$\begin{array}{c}\text { Garden } \\
\text { Compost }\end{array}$ & $8.45 \pm 0.14_{\mathrm{a}}$ & $0.419 \pm 0.022_{\mathrm{a}}$ & $3378 \pm 741_{\mathrm{b}}$ & $1258 \pm 362_{\mathrm{b}}$ & $2120 \pm 556_{\mathrm{a}}$ & $1666 \pm 242_{\mathrm{ab}}$ & $11000 \pm 895_{\mathrm{b}}$ \\
$\begin{array}{c}\text { Composted } \\
\text { Horse Manure } \\
\text { Spent }\end{array}$ & $8.33 \pm 0.09_{\mathrm{ab}}$ & $0.135 \pm 0.010_{\mathrm{cd}}$ & $3172 \pm 995_{\mathrm{b}}$ & $3079 \pm 1021_{\mathrm{b}}$ & $93 \pm 30_{\mathrm{b}}$ & $3869 \pm 624_{\mathrm{ab}}$ & $68150 \pm 4682_{\mathrm{a}}$ \\
$\begin{array}{c}\text { Mushroom } \\
\text { Compost } \\
\text { Peat }\end{array}$ & $7.63 \pm 0.19_{\mathrm{b}}$ & $0.212 \pm 0.012_{\mathrm{b}}$ & $18442 \pm 3622_{\mathrm{a}}$ & $18382 \pm 3628_{\mathrm{a}}$ & $60 \pm 23_{\mathrm{b}}$ & $6746 \pm 1315_{\mathrm{a}}$ & $100819 \pm 9973_{\mathrm{a}}$ \\
\hline
\end{tabular}

\subsection{Amendment and Soil Multivariate Analysis}

The three replications for each of the peat, garden compost and composted bark amendments resembled one another more closely than composted horse manure and spent mushroom compost on a multivariate basis (Figure 1a). This suggests that peat, garden compost and composted bark are more consistent/uniform amendments. Despite this, more uniform amendments do not result in replicates of soils treated with these materials having a closer resemblance to one another (Figure 1b). 

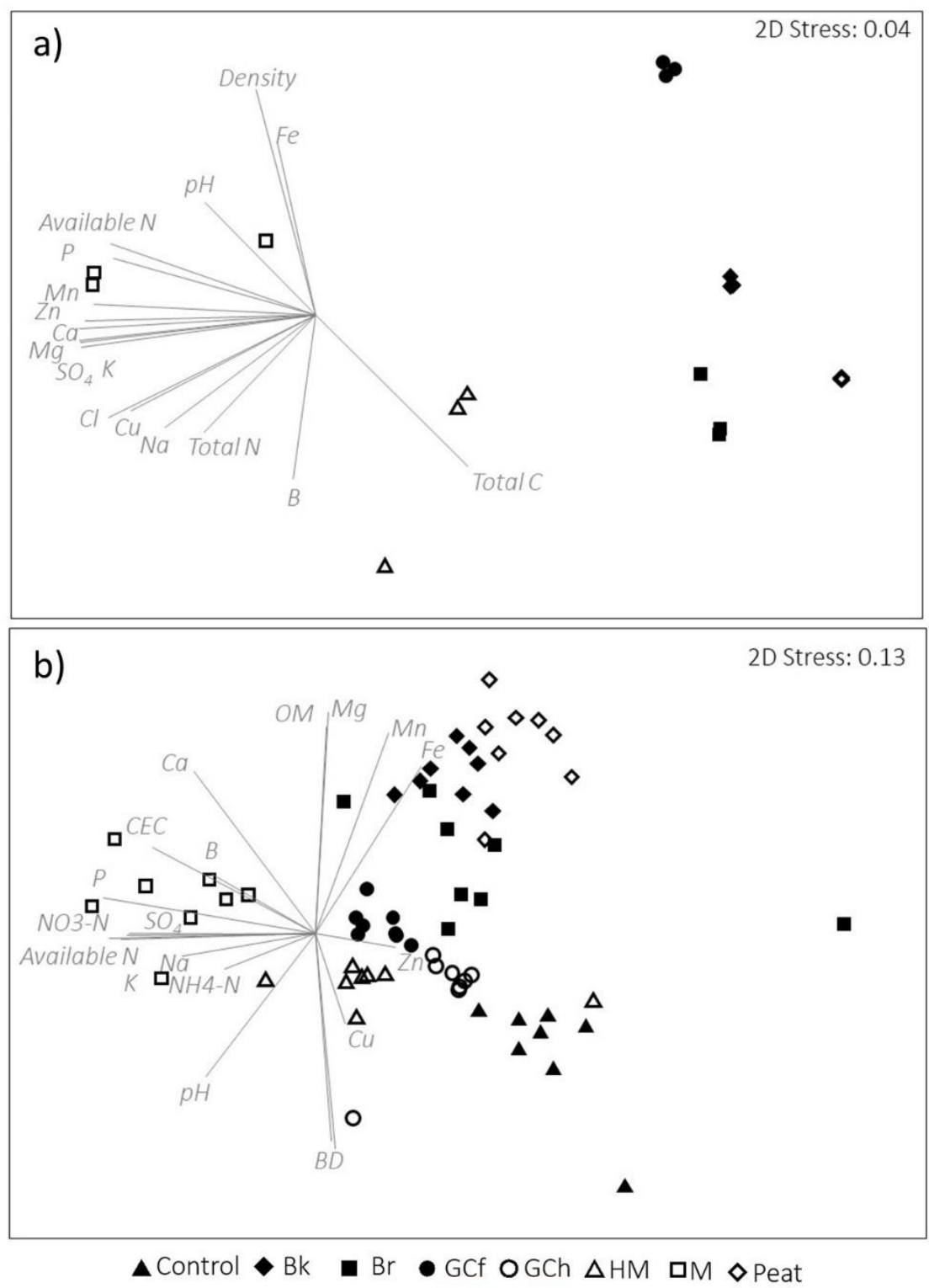

Figure 1. Effect of treatment on (a) amendment applied; and (b) post-application and harvest (September Year 7). Multidimensional scaling based on Euclidean distance with 1000 restarts, vectors labelled in grey italics. Samples: Control—no amendments applied; Bk—composted bark; $\mathrm{Br}$ —composted bracken; GCf—garden compost (full rate); GCh—garden compost (half rate); HMcomposted horse manure; $\mathrm{M}$-spent mushroom compost; Peat-Irish moss peat.

According to multidimensional scaling and ANOSIM, soils amended with organic materials are significantly different to the unamended control on a multivariate basis from year 1 , with the exception of soil treated with composted bracken which was significantly different to the control from year 2 (Table 4 ). 
Table 4. Pairwise comparisons of amendments multivariate physicochemical properties before application. $p$ values according to ANOSIM.

\begin{tabular}{cccccccc}
\hline & \multicolumn{7}{c}{ Pairwise Comparisons $p$-Values According to ANOSIM } \\
\cline { 2 - 7 } Year & $\begin{array}{c}\text { Control } \\
\text { vs. Bk }\end{array}$ & $\begin{array}{c}\text { Control } \\
\text { vs. Br }\end{array}$ & $\begin{array}{c}\text { Control } \\
\text { vs. GCh }\end{array}$ & $\begin{array}{c}\text { Control } \\
\text { vs. GCf }\end{array}$ & $\begin{array}{c}\text { Control } \\
\text { vs. HM }\end{array}$ & $\begin{array}{c}\text { Control } \\
\text { vs. } \text { M }\end{array}$ & $\begin{array}{c}\text { Control } \\
\text { vs. Peat }\end{array}$ \\
\hline 0 & 0.537 & 0.957 & 0.909 & 0.879 & 0.743 & 0.494 & 0.313 \\
1 & $<0.01$ & 0.06 & $<0.01$ & $<0.01$ & $<0.01$ & $<0.01$ & $<0.01$ \\
2 & $<0.01$ & $<0.01$ & $<0.01$ & $<0.01$ & $<0.01$ & $<0.01$ & $<0.01$ \\
3 & $<0.01$ & $<0.01$ & $<0.01$ & $<0.01$ & $<0.01$ & $<0.01$ & $<0.01$ \\
4 & $<0.01$ & $<0.01$ & $<0.01$ & $<0.01$ & $<0.01$ & $<0.01$ & $<0.01$ \\
5 & $<0.01$ & $<0.01$ & $<0.01$ & $<0.01$ & $<0.01$ & $<0.01$ & $<0.01$ \\
6 & $<0.01$ & $<0.01$ & $<0.01$ & $<0.01$ & $<0.01$ & $<0.01$ & $<0.01$ \\
7 & $<0.01$ & $<0.01$ & $<0.01$ & $<0.01$ & $<0.01$ & $<0.01$ & $<0.01$ \\
\hline
\end{tabular}

Soils treated with different amendments are significantly different from one another (see Supplementary Material, Table S2). Application rate of the garden compost also resulted in soils that are significantly different to one another. However, the half-rate application resembles the control more closely than the full-rate application (Figure 1b).

The three amendments that show the closest resemblance to one another in year 7 (composted bracken, composted bark and peat, Figure 1a) also result in soils that have a close resemblance according to multidimensional scaling (Figure 1b). Additionally, the spent mushroom compost, which had the least resemblance to the other amendments resulted in soils that had the least resemblance after harvest (Figure 1), largely driven by higher $\mathrm{N}$ and $\mathrm{P}$ content in the amendments and subsequent amended soils.

The highest absolute vectors for the soil MDS (Figure 1b) were extractable P on MDS1, and bulk density on MDS2. Temporal trends in these two variables can be found in Figure 2. All soils treated with organic amendments had an elevated extractable P concentration compared to the control (Figure 2a), with spent mushroom adding the most P. Peat and half-rate garden compost applications had the smallest effect on extractable P compared to the control.

Application of all organic amendments resulted in a reduced bulk density compared to the control (Figure $2 b$ ). Peat had the largest effect on bulk density and the half rate garden compost had the smallest effect on bulk density. Temporal data for all other individual variables can be found in the Supplementary Information (Table S3). 

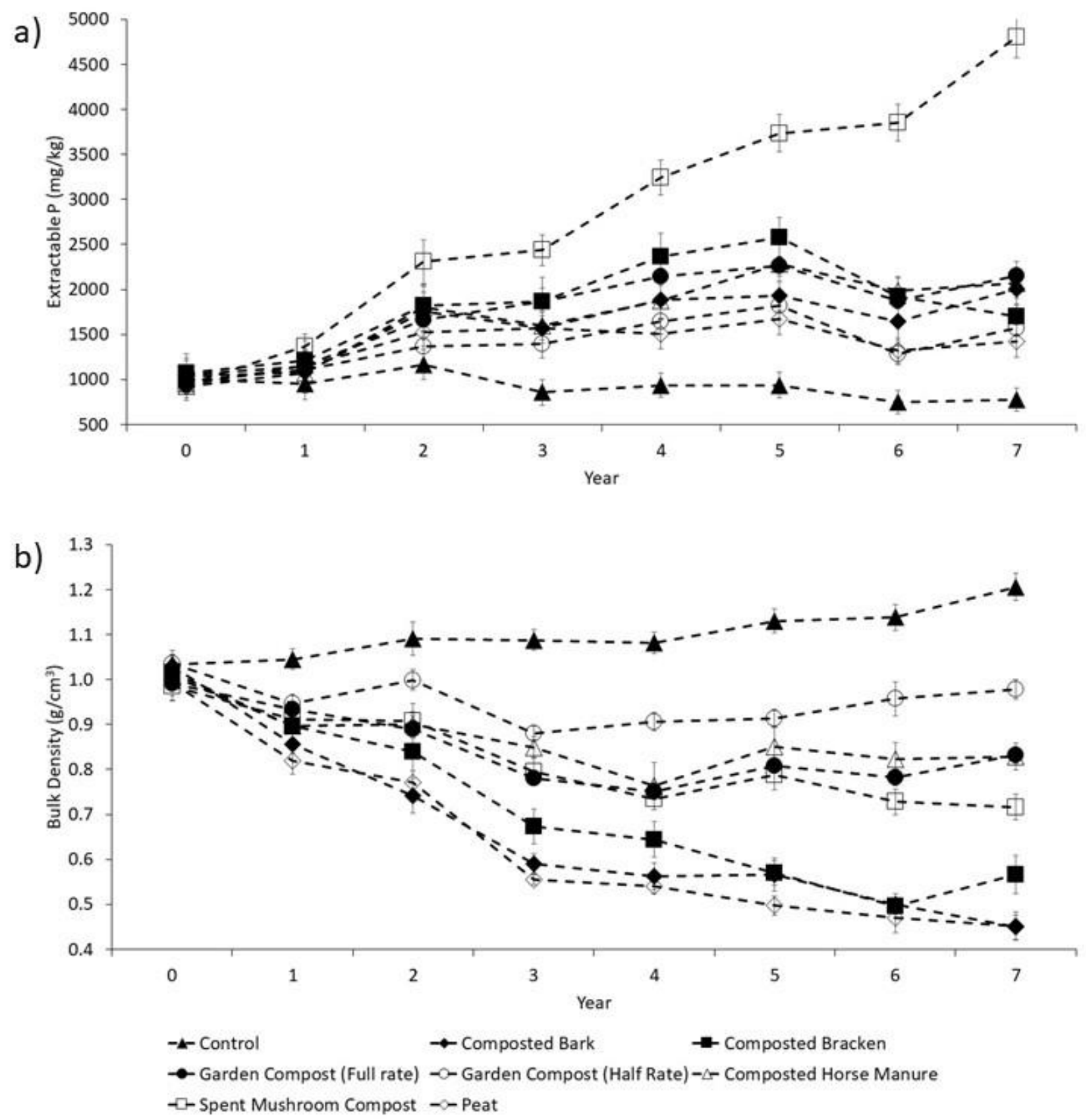

Figure 2. Temporal changes in (a) soil extractable P; and (b) bulk density in amended soils. Error bars for standard error $(n=8)$.

\subsection{Yield}

Application of composted bracken, composted horse manure, spent mushroom compost and both rates of garden compost resulted in a significantly higher yield of Lavatera trimestris than the unamended control (Figure 3). Application rate of the garden compost had no significant effect on yield.

The highest yields were observed in soils treated with garden compost and composted bracken, five times the yield obtained from the control plot. Application of peat and composted bark, on the other hand, did not result in a significantly different yield compared with the control (Figure 3). 


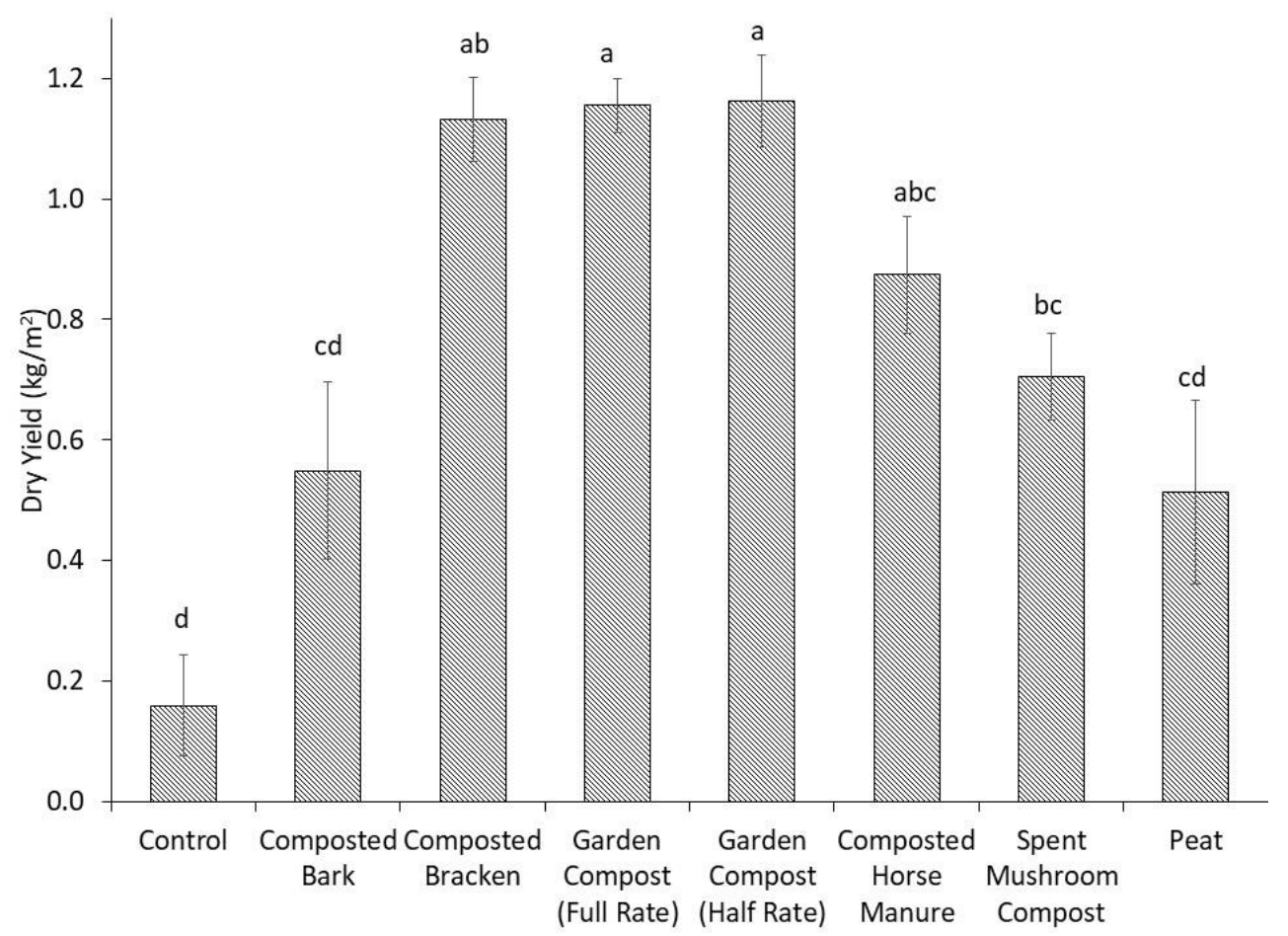

Figure 3. Effect of amendment on dry plant yield of Lavatera trimestris after 6 years of repeated application. Error bars for standard error $(n=8)$. Treatments that share the same letter above the bar are not significantly different according to one-way ANOVA and Tukey's post hoc testing $(p<0.05)$.

\subsection{Plant Biometrics}

Eight weeks after sowing, the garden compost treatments (half and full rate) had significantly more plants per $\mathrm{m}^{2}$ than the unamended control (Figure 4a). The peat and composted bark treatments had significantly fewer plants than the control (Figure 4a) and the composted bracken, horse manure and spent mushroom had no significance to the control in terms of the number of plants per $\mathrm{m}^{2}$.

There was a significantly higher proportion of plants with flowers observed on plots amended with spent mushroom compost, garden compost (half and full rate) and composted horse manure when compared with the control (Figure $4 \mathrm{~b}$ ). There was no significant difference in the proportion of plants with flowers between the control and plots amended with peat, composted bark or composted bracken.

Soils amended with composted bracken, garden compost (both rates), composted horse manure and spent mushroom compost resulted in significantly taller plants than the control (Figure 4c). Conversely, application of peat and composted bark did not result in a significant difference in plant height.

All amendment treatments, with the exception of peat, resulted in plants with significantly higher chlorophyll contents than the control (Figure 4d). There was no significant difference between the application rate of garden compost for any of the plant metrics measured.

\subsection{Plant Biomass Nutrients}

Plant biomass nutrient ratios suggest that growth of Lavatera trimestris was $\mathrm{N}$-limited. The proportions of $\mathrm{K}, \mathrm{Mg}$ and $\mathrm{Ca}$, compared to $\mathrm{N}$, were above the suggested optimum ratios given by Knecht and Göransson [16], in most instances (Figure 5). 

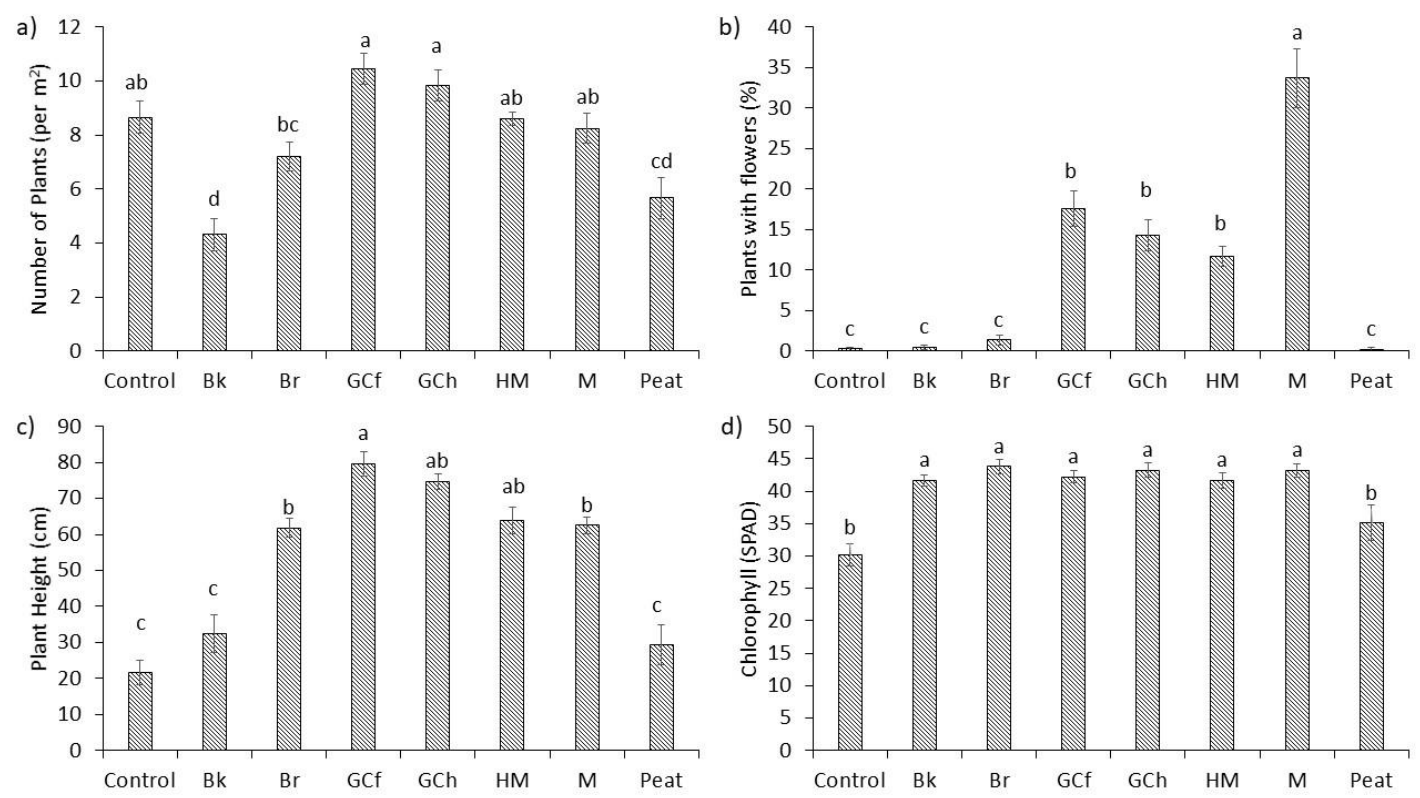

Figure 4. Effect of amendment on plant characteristics 8 weeks after sowing (a) number of plants per $\mathrm{m}^{2}$; (b) Proportion of plants that have flowers; (c) plant height; and (d) Leaf chlorophyll content. Error bars for standard error $(n=8)$. Treatments that share the same letter above the bar are not significantly different according to one-way ANOVA and Tukey's post hoc testing ( $p$ <.05). Samples: Control—no amendments applied; Bk—composted bark; Br—composted bracken; GCf—garden compost (full rate); GCh—garden compost (half rate); HM—composted horse manure; M—spent mushroom compost; Peat-Irish moss peat.
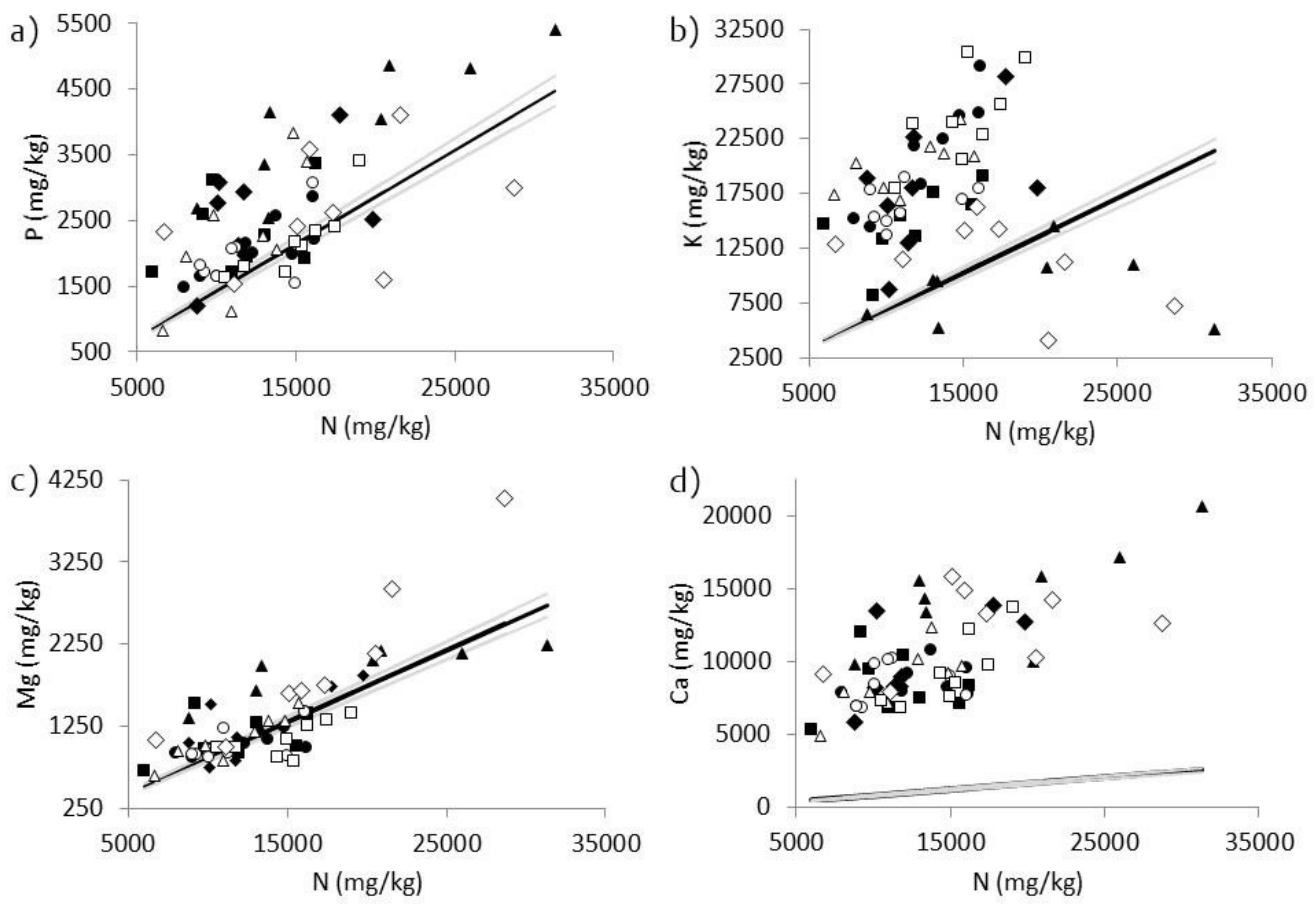

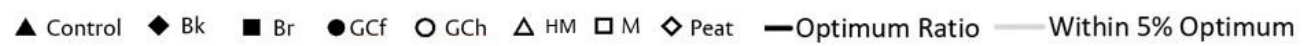

Figure 5. Plant tissue $\mathrm{N}$ concentration versus plant tissue (a) $\mathrm{P},(\mathbf{b}) \mathrm{K},(\mathbf{c}) \mathrm{Mg}$ and (d) Ca in Lavatera trimestris grown in different treatments after 6 years of repeated amendment application. Black line signifies suggested optimum nutrient ratios for herbaceous plants according to Knecht \& Göransson [16]. Grey lines for 5\% above or below the optimum. Points above the line were $\mathrm{N}$-limited, points below the line were limited by the other nutrient. Samples: Control—no amendments applied; Bk—composted bark; Br—composted bracken; GCf—garden compost (full rate); GCh—garden compost (half rate); HM-composted horse manure; $\mathrm{M}$-spent mushroom compost; Peat-Irish moss peat. 


\subsection{Plant Nitrogen-Use Efficiency}

The highest NUE was observed in composted bracken and garden compost applied at half rate (Figure 6), which had some of the highest yields (Figure 3). The lowest NUE was observed in the treatments that had the lowest yields (peat and composted bark). Garden compost applied at full rate, however, despite having one of the highest yields, had the lowest NUE.

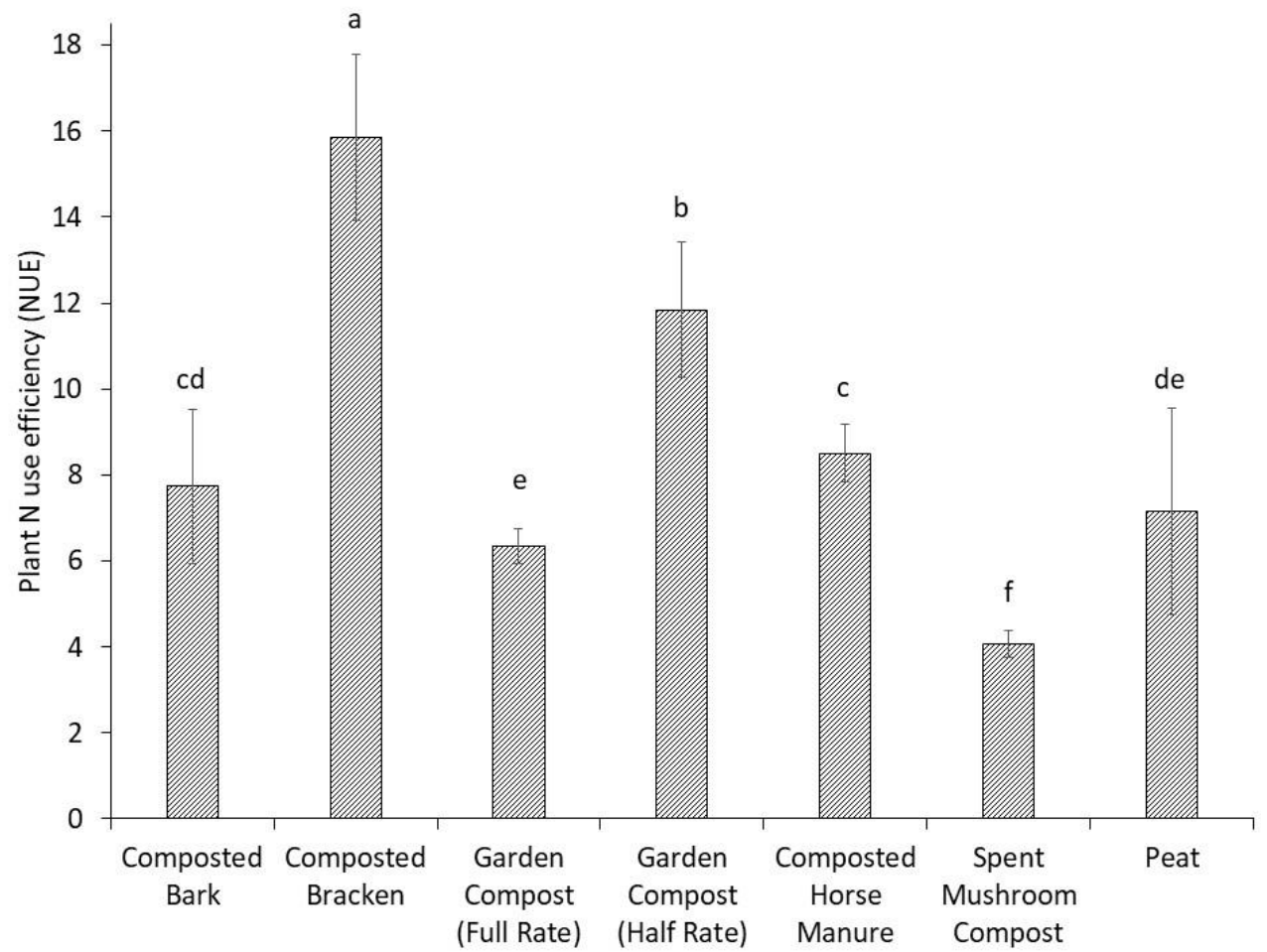

Figure 6. Effect of treatment on Lavatera trimestris nitrogen-use efficiency after 6 years of repeated amendment application. Error bars for standard error $(n=8)$. Treatments that share a letter above the bar are not significantly different according to one-way ANOVA and Tukey's post hoc testing $(p<0.05)$.

\subsection{Nitrogen Budget}

All amended treatments had a significantly higher nitrogen budget compared to the unamended control (Figure 7). The garden compost (full rate) and the spent mushroom compost treatments had significantly higher nitrogen budgets than all other treatments. Application rate of the garden compost also had a significant effect on the nitrogen budget (Figure 7).

A breakdown of the elements of the nitrogen budget can be found in the Supplementary Information (Figure S1) Total N contents of the soil just before the 7th annual application of amendments, and after amendment application and at plant harvest, was highest in the garden compost and spent mushroom compost treatments. Application of garden compost (full rate) and spent mushroom compost also resulted in the highest $\mathrm{N}$ additions. Plants grown on garden compost treatments removed the highest quantity of $\mathrm{N}$. 


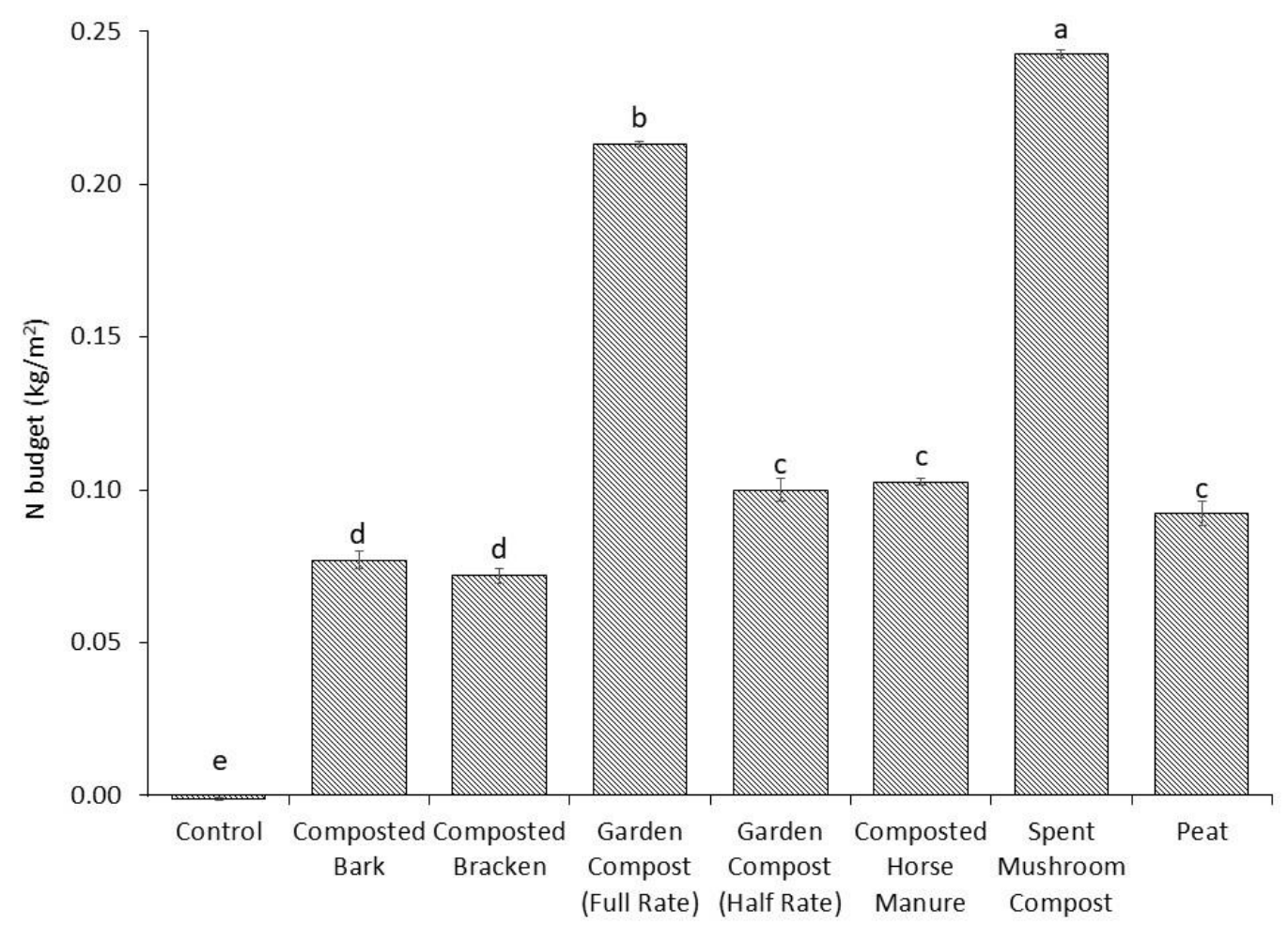

Figure 7. Nitrogen budget in Year 7 on each treatment.Error bars for standard error $(n=8)$. Treatments that share a letter above the bar are not significantly different according to one-way ANOVA and Tukey's post hoc testing $(p<0.05)$.

\section{Discussion}

\subsection{Physicochemical Properties of Organic Amendments Commonly Used in Horticulture}

Amendments chosen for this study were based on those commonly used in UK horticulture, and are widely available to UK horticulture, many of which have seldom been investigated in a horticultural context. All of the materials investigated are commonly referred to under the blanket term of 'compost' in the gardening community. However, we have demonstrated here that there was a significant difference between all of the amendments in terms of their physicochemical characteristics over the seven years we sampled them. The amendments used had different $\mathrm{pH}$ values, densities and nutrient contents, all of which will impact on the effectiveness of the material to promote plant production and aesthetics, which are key drivers for amendment selection for gardeners [1].

Amendments from the same supplier can also be variable, a study by Benito et al. [17] took 12 temporal samples from the same prunings compost waste facility and found differences between samples in electrical conductivity and C:N ratio. In our study, however, garden compost samples (along with peat and composted bark) are relatively consistent between replicate samples in year 7 . The consistency of the garden compost could be of particular interest to gardeners, as many make their own compost in their garden Although the feedstock changed throughout the year because the RHS Wisley garden regularly change their plants grown, the resultant compost generated from the prunings and cuttings from the garden remains fairly consistent. However, it is important to note that the Wisley Garden compost does not contain any municipal waste, which may be more common in domestic compost heaps (e.g., vegetable peelings, paper, etc.). Other amendments, such as spent mushroom compost were less consistent. This is in concordance with Jordan et al. [18] who observed that there was a significant difference in spent mushroom compost sourced from different locations. 


\subsection{Amended Soil Physicochemical Properties and N Budget}

Amendment application can improve plant production through improvement of soil characteristics favourable to plant growth such as $\mathrm{pH}$, moisture content, soil structure (oxygen supply) and nutrient supply [19]. We observed a significantly different multivariate environment in soils treated with organic amendments compared with the control that received no amendments. However, the variability in amendments in this study, discussed above, led to a large variability in the conditions of amended soils. In essence, the extent of change compared to the control depended on the amendment applied. The nutrient supply depends on the quality of the residues used and its application rate [4] and therefore varies between our treatments. For example, amendments that resembled one another prior to application resulted in soils that more closely resembled one another post application.

The concentration of nutrients applied to the soil alone does not necessarily indicate what is available to plants in a soil system. Imbalances in the ratios of nutrients in plant tissue can indicate a nutrient limitation in plant growth [20]. Therefore, analysis of the plant material itself can provide important information on the nutrient status of a horticultural soil. Despite having received high volumes of organic amendment, Lavatera trimestris were still growing in a potentially N-limited environment in the majority of samples, regardless of which amendment was selected [21-23]. However, the optimum levels presented in this research are not based on Lavatera trimestris specifically. This interpretation of plant nutrient content was also based on the assumption that Lavatera trimestris does not take up nutrients in quantities exceeding their requirements for growth, which may not be the case [16].

The $\mathrm{N}$ budget of the soil was influenced by the amendment applied. For example, soils that were treated with spent mushroom compost, the amendment containing among the highest levels of $\mathrm{N}$, in turn resulted in one of the highest levels of $\mathrm{N}$ in the soils. This was most likely a result of an $\mathrm{N}$ uptake that did not match $\mathrm{N}$ input and thus a lower $\mathrm{N}$-use efficiency in this treatment. Despite having the highest $\mathrm{N}$ budget, spent mushroom compost did not result in the highest yield, suggesting that other factors are also contributing to yield in amended soils. The $\mathrm{N}$ budget, however, will not have the same implications for $\mathrm{N}$-fixing leguminous species. Therefore, selecting an amendment tailored to the plants that gardeners intend to grow is vital.

Plant response to organic amendments is not a result of one single factor, but a complex combination of a number of chemical, physical and biological variables [14]. Furthermore, different plant types (and even cultivars) will have different requirements. For example, Ferreras et al. [24] found no difference in broccoli yield between controls and plots receiving organic amendments, but there was a significant difference in lettuce yield. This further highlights the need for greater understanding in the gardening community of the variability in organic amendments, and that selection should be tailored to the plants they wish to grow. Gardeners are often 'creatures of habit' when it comes to applying organic amendments, if they find a material they like they stick to it. However, this practice may not be effective if they are growing different annual plants every year or have different species growing in different areas of their gardens, for example.

\subsection{Effect of Amendment Application on Plant Production}

Application of garden compost (both application rates), composted bracken, composted horse manure and spent mushroom compost increased the dry-bulk yield of Lavatera trimestris compared to the unamended control. Application of peat and composted bark, however, did not increase yields compared to the control. Organic amendments can stimulate seed germination and root initiation, and improve emergence [2,3]. However, application of peat and composted bark did not result in a higher number of plants than the control, suggesting that stimulation of seed germination is not taking place as readily in these treatments. Furthermore, application of peat and composted bark also did not increase the height of the plants compared to the control, suggesting that conditions were not as favourable for plant growth as those in other amended plots. This is further evidenced 
by the fact that plants grown on peat also had significantly lower chlorophyll contents in their leaves, an important indicator of plant health [25]. This finding has implications as there is increasing pressure to phase out peat-based amendments in domestic gardening products.

Lavatera trimestris is an ornamental plant, therefore measuring just biomass on a yield basis may not be of interest to gardeners who are likely planting for aesthetic purposes. Furthermore, Lavatera trimestris is also listed as an important plant for pollinators in UK gardens by the Royal Horticultural Society [26]. Therefore, parameters such as number of flowers are important for gardeners. Peat, composted bark, and composted bracken, did not result in a significantly higher proportion of flowers when compared to the control. Spent mushroom compost on the other hand had a significantly higher proportion of plants with flowers after 8 weeks, despite not having the highest dry-bulk yield. The highlights the need for different metrics to be considered in the examination of horticultural plants. Nitrogen has been reported to regulate flowering time but while some studies have shown that lower nitrogen promoted flowering, others have reported the opposite [27]. In this research the spent mushroom compost treatment, with the highest nitrogen budget, had the highest proportion of flowering plants.

The variability in the different amendments investigated in our research, in addition to the variable effects on plant growth parameters, suggests that repeated use of a single amendment may not be best practice for gardeners. Particularly as gardeners are more likely to be growing an array of plant species in their garden, compared to agriculture. For example, garden compost had the highest yield, but spent mushroom compost had the highest number of flowers, suggesting a combination of the two may benefit gardeners. Research by González et al. [28] have suggested that crop production parameters and biological activity was improved when a combination of amendments was used, when compared to soils treated with a single amendment.

Application rate of garden compost had a significant effect on the soil physicochemical environment. However, application rate did not result in a significant difference in dry-bulk yield, number of plants, proportion of flowers, plant height or chlorophyll content. In order to improve yield, it is not just about the gross concentrations of nutrients contained within an amendment, but the proportions of these nutrients in relation to one another. This accounts for the fact that doubling the application rate of garden compost did not result in higher yields. Therefore, in this case, half-rate application of garden compost is sufficient to supply the needs of Lavatera trimestris, further evidenced by the lower NUE in the full-rate application of garden compost. This has obvious implications for gardeners, as reducing application rates save resources (cost, time, labour, etc.).

\subsection{Further Work}

This research has highlighted that there are fundamental differences between amendments commonly used/available for use by gardeners, in terms of the multivariate environment they produce, the $\mathrm{N}$ budget and plant production. However, in order to unpack the reasons for these differences, more analysis is required on the soils from these experimental plots. For example, the resultant soil organic carbon from amendment application and the microbial community structure of amended soils.

Soil organic carbon (SOC), contained in soil organic matter (SOM), is commonly referred to as one of the most important indicators of soil quality [29]. It governs an array of soil physical, chemical and biological processes [30,31] and therefore the soils ability to stimulate plant growth. Decomposition of SOM is an important process for nutrient supply to plants because it liberates nutrients once held in organic complexes, making them available for utilisation by plants for growth [10]. However, the fate and behaviour of SOM are also influenced, in turn, by the physical, chemical and biological properties of the soil $[28,32]$. Therefore, an understanding of SOM contents and persistence of the SOM fractions of the soil is vital in order to understand the mechanisms responsible for the differences observed in this research. 
Soil organic matter (SOM) composition has been found to influence microbial biomass, respiration and community structure [33] and subsequent decomposition of these materials. Soil microorganisms play a vital role in a variety of soil functions, including decomposition, aggregation and biogeochemical cycling [34]. It has also been suggested that microbialderived carbon compounds are of vital importance to SOM stability in soils [35]. Therefore, soil microbial community structure and activities, including respiration, enzymatic activities and microbial biomass are important factors in determining soil quality [36,37], which can be closely related to SOM content and quality of the organic amendment [34,37]. An understanding of the microbial community will also aid our understanding of the nitrogen budget. Due to the fact that nitrogen can be mineralised at all levels of the soil food web, release of $\mathrm{N}$ will benefit from a diverse microbial community [38].

\section{Conclusions}

Application of organic amendments to soil is commonplace in domestic gardening. However, a vast array of materials could be labelled as 'compost' by retailers and suppliers. Here, we have demonstrated that different organic amendments can result in significantly different results in terms of plant yield and aesthetics, which is a consequence of the different soil environments and $\mathrm{N}$ budgets that the amendments create.

Gardeners are often 'creatures of habit' when it comes to applying organic amendments, if they find a material they like they stick to it. However, the variable effects on plant growth parameters suggests that repeated use of a single amendment may not be best practice for gardeners. This is particularly the case when gardeners are likely to be growing an array of plant species in their garden (some legumes, some not), and different annual plants every year. Furthermore, gardeners are more likely to grow different species in different areas of their gardens, so using the same material throughout may not be appropriate. We have also demonstrated here that peat, which is being phased out of horticultural use, did not perform as well as peat-free alternatives.

Supplementary Materials: The following are available online at https:/ /www.mdpi.com/article/ 10.3390/horticulturae7100371/s1, Figure S1: Effect of treatment on components of nitrogen budget in year 7, Table S1: Annual crops sown on Wisley organic matter plots, Table S2: Results of analysis of similarity (ANOSIM) of soil physicochemical properties, Table S3: Temporal soil physicochemical properties.

Author Contributions: Conceptualization, S.D., P.D.A., L.J.S., C.D.C.; methodology, S.D., P.D.A., L.J.S., C.D.C.; formal analysis, S.D.; data curation, S.D. and P.D.A.; writing-original draft preparation, S.D.; writing-review and editing, S.D., P.D.A., L.J.S., C.D.C..; visualization, S.D.; supervision, P.D.A., L.J.S. and C.D.C.; funding acquisition, P.D.A., L.J.S. and C.D.C. All authors have read and agreed to the published version of the manuscript.

Funding: This research was supported by an Industrial Co-Operative Award in Science and Engineering (CASE), jointly funded by the Biotechnology and Biological Sciences Research Council (BBSRC), the Royal Horticultural Society (RHS), and the Department for Environment, Food, and Rural Affairs (Defra).

Institutional Review Board Statement: Not applicable.

Informed Consent Statement: Not applicable.

Data Availability Statement: Data available on request.

Acknowledgments: The authors would like to thank Rachael Tanner (Royal Horticultural Society) for her technical support managing the field site.

Conflicts of Interest: The authors declare no conflict of interest. 


\section{References}

1. Alexander, P.D.; Nevison, I.M. The long-term effects of repeated application of the same organic material to soil in a horticultural context. Acta Hortic. 2015, 1076, 143-150. [CrossRef]

2. Christensen, B.T. Physical fractionation of soil and structural and functional complexity in organic matter turnover. Eur. J. Soil Sci. 2001, 52, 345-353. [CrossRef]

3. Lima, D.; Santos, S.M.; Scherer, H.W.; Schneider, R.J.; Duarte, A.C.; Santos, E.; Esteves, V.I. Effects of organic and inorganic amendments on soil organic matter properties. Geoderma 2009, 150, 38-45. [CrossRef]

4. Roy, S.; Arunachalam, K.; Dutta, B.K.; Arunachalam, A. Effect of organic amendments of soil on growth and productivity of three common crops viz. Zea mays, Phaseolus vulgaris and Abelmoschus esculentus. Appl. Soil Ecol. 2010, 45, 78-84. [CrossRef]

5. Thangarajan, R.; Bolan, N.S.; Tian, G.; Naidu, R.; Kunhikrishnan, A. Role of organic amendment application on greenhouse gas emission from soil. Sci. Total Environ. 2013, 465, 72-96. [CrossRef] [PubMed]

6. Albiach, R.; Canet, R.; Pomares, F.; Ingelmo, F. Microbial biomass content and enzymatic activities after the application of organic amendments to a horticultural soil. Bioresour. Technol. 2000, 75, 43-48. [CrossRef]

7. Magdoff, F.; Weil, R.R. Soil organic matter strategies. In Soil Organic Matter in Sustainable Agriculture; Magdoff, F., Weil, R.R., Eds.; CRC Press: London, UK, 2004; pp. 45-66.

8. Reid, K. Improving your Soil: A Practical Guide to Soil Management for the Serious Home Gardener; Firefly Books Ltd.: Richmond Hill, ON, Canada, 2014.

9. Tahboub, M.B.; Lindemann, W.C.; Murray, L. Chemical and physical properties of soil amended with pecan wood chips. HortScience 2008, 43, 891-896. [CrossRef]

10. Paterson, E.; Neilson, R.; Midwood, A.J.; Osborne, S.M.; Sim, A.; Thornton, B.; Millard, P. Altered food web structure and C-flux pathways associated with mineralisation of organic amendments to agricultural soil. Appl. Soil Ecol. 2011, 48, 107-116. [CrossRef]

11. Murphy, E. Building Soil: A Down-to-Earth Approach; Cool Springs Press: Beverly, MA, USA, 2015.

12. RHS. Organic Matter: How to Use in the Garden; RHS: London, UK, 2021. Available online: https://www.rhs.org.uk/advice/ profile?PID=865 (accessed on 5 August 2021).

13. Verdonck, O. Composts from organic waste materials as substitutes for the usual horticultural substrates. Biol. Wastes 1988, 26, 325-330. [CrossRef]

14. Rinaldi, S.; De Lucia, B.; Salvati, L.; Rea, E. Understanding complexity in the response of ornamental rosemary to different substrates: A multivariate analysis. Sci. Hortic. 2014, 176, 218-224. [CrossRef]

15. MAFF. Bulletin RB 427-The analysis of Agricultural Materials; The Ministry of Agriculture, Fisheries and Food (MAFF): London, UK, 1981.

16. Knecht, M.F.; Göransson, A. Terrestrial plants require nutrients in similar proportions. Tree Physiol. 2004, 24, 447-460. [CrossRef] [PubMed]

17. Benito, M.; Masaguer, A.; Moliner, A.; De Antonio, R. Chemical and physical properties of pruning waste compost and their seasonal variability. Bioresour. Technol. 2006, 97, 2071-2076. [CrossRef]

18. Jordan, S.N.; Mullen, G.J.; Murphy, M.C. Composition variability of spent mushroom compost in Ireland. Bioresour. Technol. 2008, 99, 411-418. [CrossRef]

19. Fenner, M.; Thompson, K. The Ecology of Seeds; Cambridge University Press: Cambridge, UK, 2005.

20. Uchida, R. Recommended Plant Tissue Nutrient Levels. In Plant Nutrient Management in Hawaii's Soils: Approaches for Tropical and Subtropical Agriculture; Silva, J.A., Uchida, R., Eds.; College of Tropical Agriculture and Human Resources, University of Hawaai: Honolulu, HI, USA, 2000; pp. 57-65.

21. Koerselman, W.; Meuleman, A.F.M. The Vegetation N:P Ratio: A New Tool to Detect the Nature of Nutrient Limitation. J. Appl. Ecol. 1996, 33, 1441. [CrossRef]

22. Güsewell, S. N:P ratios in terrestrial plants: Variarion and functional significance. New Phytol. 2004, 164, 243-266. [CrossRef]

23. Veresoglou, S.D.; Shaw, L.J.; Sen, R. Glomus intraradices and Gigaspora margarita arbuscular mycorrhizal associations differentially affect nitrogen and potassium nutrition of Plantago lanceolata in a low fertility dune soil. Plant Soil 2011, 340, 481-490. [CrossRef]

24. Ferreras, L.; Gomez, E.; Toresani, S.; Firpo, I.; Rotondo, R. Effect of organic amendments on some physical, chemical and biological properties in a horticultural soil. Bioresour. Technol. 2006, 97, 635-640. [CrossRef]

25. Pavlovic, D.; Nikolic, B.; Durovic, S.; Waisi, H.; Andelkovic, A.; Marisavljevic, D. Chlorophyll as a measure of plant health: Agroecological aspects. Pestic. Phytomed. 2014, 29, 21-34. [CrossRef]

26. RHS. Lavatera Trimestris. R Hortic Soc n.d. Available online: https://www.rhs.org.uk/plants/119872/i-lavatera-trimestris-i/ details (accessed on 28 September 2021).

27. Lin, Y.; Tsay, Y. Influence of differing nitrate and nitrogen availability on flowering control in Arabidopsis. J. Exp. Bot. 2017, 68, 2603-2609. [CrossRef] [PubMed]

28. González, M.; Gomez, E.; Comese, R.; Quesada, M.; Conti, M. Influence of organic amendments on soil quality potential indicators in an urban horticultural system. Bioresour. Technol. 2010, 101, 8897-8901. [CrossRef]

29. Ghosh, S.; Wilson, B.; Ghoshal, S.; Senapati, N.; Mandal, B. Organic amendments influence soil quality and carbon sequestration in the Indo-Gangetic plains of India. Agric. Ecosyst. Environ. 2012, 156, 134-141. [CrossRef] 
30. Olk, D.C.; Gregorich, E.G. Overview of the Symposium Proceedings, Meaningful Pools in Determining Soil Carbon and Nitrogen Dynamics. Soil Sci. Soc. Am. J. 2006, 70, 967-974. [CrossRef]

31. Pérez-Piqueres, A.; Edel-Hermann, V.; Alabouvette, C.; Steinberg, C. Response of soil microbial communities to compost amendments. Soil Biol. Biochem. 2006, 38, 460-470. [CrossRef]

32. Gerzabek, M.H.; Haberhauer, G.; Kandeler, E.; Sessitsch, A.; Kirchmann, H. Response of organic matter pools and enzyme activities in particle size fractions to organic amendments in a long-term field experiment. Dev. Soil Sci. 2002, 28, 329-344.

33. Baumann, K.; Marschner, P.; Smernik, R.J.; Baldock, J.A. Residue chemistry and microbial community structure during decomposition of eucalypt, wheat and vetch residues. Soil Biol. Biochem. 2009, 41, 1966-1975. [CrossRef]

34. Kallenbach, C.; Grandy, A.S. Controls over soil microbial biomass responses to carbon amendments in agricultural systems: A meta-analysis. Agric. Ecosyst. Environ. 2011, 144, 241-252. [CrossRef]

35. Kleber, M.; Nico, P.; Plante, A.; Filley, T.; Kramer, M.; Swanston, C.; Sollins, P. Old and stable soil organic matter is not necessarily chemically recalcitrant: Implications for modeling concepts and temperature sensitivity. Glob. Chang. Biol. 2011, 17, 1097-1107. [CrossRef]

36. Gomez, E.; Ferreras, L.; Toresani, S. Soil bacterial functional diversity as influenced by organic amendment application. Bioresour. Technol. 2006, 97, 1484-1489. [CrossRef]

37. Ge, G.; Li, Z.; Zhang, J.; Wang, L.; Xu, M.; Wang, J.; Xie, X.; Liang, Y. Geographical and climatic differences in long-term effect of organic and inorganic amendments on soil enzymatic activities and respiration in field experimental stations of China. Ecol. Complex. 2009, 6, 421-431. [CrossRef]

38. Gunapala, N.; Venette, R.C.; Ferris, H.; Scow, K.M. Effects of soil management history on the rate of organic matter decomposition. Soil Biol. Biochem. 1998, 30, 1917-1927. [CrossRef] 